Avalaible online: https://ejournal.iai-tribakti.ac.id/index.php/pgmi

Article doi: https://doi.org/10.33367/iiee.v1i2.1350

\title{
Pengembangan Pendekatan Somatic - Auditory - Visualization Intellectually (SAVI) Dalam Meningkatkan Kemampuan Pemecahan Masalah Pada Mata Pelajaran Fikih Melalui Pembelajaran Jarak Jauh; Studi Di MTs Nidhomiyah Surowono Kecamatan Badas Kabupaten Kediri
}

\author{
Haizatul Masnaiyah ${ }^{1}$, Sri Susanti Tjahja Dini ${ }^{2}$, \\ ${ }^{1}$ Institut Agama Islam Tribakti Kediri, ${ }^{2}$ Institut Agama Islam Tribakti Kediri, ${ }^{3}$ institut \\ Agama Islam Tribakti Kediri \\ I'haizatulmasnaiyah@gmail.com, ${ }^{2}$ santi_tjahjadini@yahoo.co.id ,
}

\begin{abstract}
The outbreak of the corona virus desease (Covid 19) in Indonesia has prompted the Ministry of Education and Culture and the Ministry of Religion to urge schools to organize the distance learning. Because of this appeal, schools and madrasas organize the distance learning activities, including MTs Nidhomiyah Surowono, Badas District. However, the distance learning of fiqh subjects is only providing assignments through the WA group and there is no feedback from the teacher. This phenomena causes the problems solving skills of the students became low. So research and development ( $R \& D$ ) was done on the fiqh subjects to describe 1) the steps for developing somatic-auditory-visualization-intellectually (SAVI) approach through distance learning, and 2) the effectiveness of developing somatic-auditory-visualization-intellectually approach (SAVI) to increase the problem solving skills on the fiqh subjects through distance learning. This research used the research and development ( $R \& D)$ approach Borg and Gall model that combined with the ADDIE model. The testing model used experimental pretest-posttest control group design. The result of pretest and posttest were analyzed by test of normality, homogeneity, Ngain scores and independent sample t-test with IBM SPSS Statistics version 21. The results showed that the SAVI approach was quite effective in improving students' problem-solving skills. This can be seen based on the results of the pre test and post test in the experimental class compared to the control class. From the experimental class, it was obtained that the pre-test results had an average of 52, but after receiving the SAVI approach, the post-test score was 67. Far different from the control class whose initial class average score was 49 to 56. This is also supported by the mean results of $N$-gain score for the experimental class was 33.5513 or 33.6 which was included in the moderate or moderately effective criteria.
\end{abstract}

Key Words: Development of SAVI Approach, Problem Solving Skills, Fiqh Subjects, Distance Learning

Abstrak
Merebaknya infeksi virus Covid 19 di Indonesia membuat Mendikbud dan
Kemenag menghimbau sekolah-sekolah untuk melaksanakan pembelajaran
secara jarak jauh. Atas himbauan tersebut, sekolah dan madrasah melakukan
kegiatan pembelajaran jarak jauh, termasuk MTs Nidhomiyah Surowono
Kecamatan Badas. Namun, pembelajaran yang dilakukan pada mata pelajaran
el Bidayah: Journal of Islamic Elementary Education
Volume 2, Nomor 2, Septem6er 2020


fikih hanya sebatas pemberian tugas melalui grup WA dan tidak ada umpan balik dari guru. Hal tersebut mengakibatkan rendahnya kemampuan pemecahan masalah yang dikuasai peserta didik. Maka dilakukanlah penelitian dan pengembangan ( $R$ \& D) pada mapel fikih dengan tujuan untuk mendeskripsikan 1) langkah-langkah pengembangan pendekatan somatisauditory-visualization-intellectually (SAVI) melalui pembelajaran jarak jauh, dan 2) efektivitas pengembangan pendekatan somatis-auditory-visualizationintellectually (SAVI) dalam meningkatkan kemampuan pemecahan masalah fikih melalui pembelajaran jarak jauh. Penelitian dan pengembangan (R \& D) yang digunakan dalam penelitian ini adalah model Borg and Gall yang kombinasikan dengan model ADDIE. Uji coba model dalam penelitian ini menggunakan bentuk desain eksperimen pretest-posttest control group desain. Data pretest dan posttest yang diperoleh dianalisis dengan uji normalitas, homogenitas, Ngain score dan uji independet sampel t tes dengan bantuan aplikasi IBM SPSS Statistics versi 21. Hasil penelitian menunjukkan pendekatan SAVI cukup efektif dalam meningkatkan kemampuan pemecahan masalah yang dikuasai siswa. Hal ini dapat dilihat berdasarkan hasil dari pre test dan pos test pada kelas eksperimen yang dibandingkan dengan kelas kontrol. Dari kelas eksperimen diperoleh hasil pre test memiliki rata-rata 52 namun setelah mendapat perlakuan pendekatan SAVI diperoleh nilai post test 67. Jauh berbeda dengan kelas kontrol yang nilai rata-rata kelas yang awalnya adalah 49 menjadi 56. Hal ini didukung pula dengan hasil rata-rata N-gain score kelas eksperimen sebesar 33,5513 atau 33,6 yang masuk dalam kriteria sedang atau cukup efektif.

Kata Kunci : Pengembangan Pendekatan SAVI, Kemampuan Pemecahan Masalah, Fikih, Pembelajaran Jarak Jauh

\section{Pendahuluan}

Pendidikan dalam Undang-undang Sistem Pendidikan Nasional No. 20 tahun 2003 didefinisikan sebagai usaha sadar dan terencana untuk mewujudkan suasana belajar dan proses pembelajaran agar peserta didik secara aktif mengembangkan potensi dirinya untuk memiliki kekuatan spiritual keagamaan, pengendalian diri, kepribadian, kecerdasan, akhlak mulia, serta ketrampilan yang diperlukan dirinya, masyarakat, bangsa, dan Negara. ${ }^{1} \mathrm{Hal}$ ini mengandung pengertian bahwa pendidikan yang diselenggarakan tidak hanya bertujuan untuk membentuk peserta didik yang memahami ma-

${ }^{1}$ Depdiknas, Undang-undang RI Nomor 20 Tahun 2003 Tentang Sistem Pendidikan Nasional, 2003, h. 2.

2 Sepriani Trimurtini Limbong, "Virus Corona - Penyebab, Gejala dan Pencegahan el Bidayah: Journal of Islamic Elementary Education Volume 2, Nomor 2, September 2020 teri semata, namun juga memiliki kepribadian dan keterampilan yang akan menjadi bekal dalam kehidupannya, termasuk keterampilan dalam menghadapi setiap per-soalan yang muncul di tengah masyarakat.

Tujuan pendidikan tersebut menjadi nafas setiap penyelenggaraan lembaga pendidikan yang ada di Indonesia. Namun, untuk meraihnya penuh dengan tantangan. Apalagi di tengah situasi merebaknya infeksi virus Covid 19 di tengah masyarakat saat ini. Infeksi virus Covid 19 merupakan penyakit yang disebabkan oleh virus corona dan menimbulkan gejala utama berupa gangguan pernapasan. ${ }^{2}$

Klikdokter.com," diakses 26 Juni 2020, https://www.klikdokter.com/penyakit/corona virus. 
Cepatnya penyebaran infeksi virus ini, membuat WHO menetapkan virus Covid 19 ini sebagai pandemi dan memberi peringatan kepada seluruh dunia bahwa virus ini dapat menyerang siapa saja dan negara mana saja di dunia. Oleh karena itu, seluruh negara harus mengantisipasi dan merespon serta waspada. Merespon hal tersebut, Presiden Joko Widodo pada tanggal 15 Maret 2020 memberikan himbauan agar masyarakat tetap tenang dan mulai berkegiatan di rumah saja. Bekerja dari rumah, belajar dari rumah dan beribadah di rumah.

Setelah mendapat himbauan tersebut, Menteri Pendidikan dan Kebudayaan kemudian menerbitkan SE Nomor 4 Tahun 2020 tentang Pelaksanaan Kebijakan Pendidikan Dalam Masa Darurat Penye-baran Coronavirus Disease (Covid-19), yang salah satunya berisi tentang pelaksanaan belajar mengajar dilakukan dengan pembe-lajaran jarak jauh atau daring. ${ }^{3}$ Kementerian Agama (Kemenag), yang mengawasi Ma-drasah, mengikuti himbauan tersebut de-ngan mengeluarkan Surat Edaran Nomor B686.1/DJ.I.I/PP.00/03/2020.

Pembelajaran jarak jauh atau yang lebih sering disebut dengan pembelajaran daring merupakan pembelajaran berbasis teknologi yang mana bahan belajarnya dikirim secara elektronik melalui jaringan komputer kepada peserta didik jarak jauh. ${ }^{4}$ Berbeda dengan pembelajaran konvensional pada umumnya, pembelajaran jarak jauh memiliki fleksibilitas dari segi waktu maupun tempat dan tidak mengharuskan adanya tatap muka secara langsung. Hal ini sangat sesuai dengan kondisi saat merebaknya infeksi Covid 19 saat ini. Namun, dalam prakteknya pembelajaran ini sangatlah bergantung pada bantuan teknologi. ${ }^{5}$ Sehingga bagi peserta didik yang tidak

3 Roida Pakpahan dan Yuni Fitriani, "Analisa Pemanfaatan Teknologi Informasi Dalam Pembelajaran Jarak Jauh Di Tengah Pandemi Virus Corona Covid-19," Journal of Information System, Applied, Management, Accounting and Research 4, no. 2 (19 Mei 2020): h. 31-32.

4 Roman Andrianto Pangondian, Paulus Insap Santosa, dan Eko Nugroho, "Faktor Faktor Yang Mempengaruhi Kesuksesan 78 memiliki fasilitas akses teknologi akan mengalami kesulitan dalam mengikutinya. Belum lagi jika pendidik sendiri kurang begitu menguasai teknologi informasi yang ada. Faktor dari karakteristik peserta didik yang memiliki ketrampilan dasar dan disiplin diri yang tinggi juga sangat menentukan keberhasilan pembelajaran daring. ${ }^{6}$ Sehingga pembelaja-ran daring ini akan mengalami kendala apabila dihadapkan pada peserta didik yang kurang memiliki disiplin diri.

Hal yang serupa juga peneliti temui pada mata pelajaran fikih di MTs Nidhomiyah Surowono. Dalam prakteknya, pembelajaran fikih selama masa pandemi ini dilakukan sebatas pemberian tugas yang ada di buku LKS yang diberitahukan melalui grup kelas di whatsapp. Kemudian tidak ada pengecekan hasil tugas siswa yang diberikan karena guru pamong sendiri kurang menguasai penggunaan teknologi informasi. Padahal berdasarkan wawancara dengan waka kurikulum, peserta didik sebenarnya sudah terbiasa dengan mengerjakan tugas secara daring. Hal tersebut sudah dilakukan pada beberapa mata pelajaran lain dengan pemberian tugas yang dikerjakan lewat online melalui google form. Diakui memang, bahwa untuk penggunaan aplikasi video telekonference peserta didik belum menguasai.

Perkembangan jumlah penderita Covid-19 terus meningkat. Tidak ada yang dapat memprediksi kapan akan berakhir. Sedangkan waktu terus bergulir. Pendidikan juga tetap harus berjalan. Peserta didik harus tetap mendapatkan haknya memperoleh pendidikan yang dapat membekali dirinya menguasai keterampilan yang dibutuhkannya dalam kehidupan meskipun dalam keadaan pandemi. Apalagi di era abad

Pembelajaran Daring Dalam Revolusi Industri 4.0," Seminar Nasional Teknologi Komputer \& Sains (SAINTEKS) 1, no. 1 (21 Februari 2019): hlm. 57, https://www.prosiding.seminarid.com/index.php/sainteks/article/view/122.

5 Pangondian, Santosa, dan Nugroho, h. 57. 58. 
21 saat ini persoalan semakin kompleks dan tuntutan zaman semakin kompetitif. Pendidik hendaknya tetap mendorong peserta didik untuk memiliki kecakapan abad 21 dalam pembelajarannya meskipun pembelajaran harus dilakukan daring. Sebagaimana dijelaskan dalam KMA Nomor 183 Tahun 2019 proses pembelajaran yang dilakukan guru haruslah mampu mendorong peserta didik untuk memiliki memiliki kecakapan abad 21 yang mampu mencari tahu dari berbagai sumber, berpikir analitis dan kerjasama serta berkolaborasi dalam menyelesaikan masalah, serta mendorong peserta didik untuk mengembangkan kreativitas berpikir yang dapat meningkatkan kemampuan peserta didik dalam mengonstruksi pengetahuan baru sebagai upaya untuk meningkatkan penguasaan materi. ${ }^{7}$

Sesuai amanat KMA di atas maka proses pembelajaran yang dilakukan haruslah membekali peserta didik untuk memiliki kemampuan dalam menyelesaikan masalah, termasuk di dalamnya adalah pembelajaran fikih. Sebagai salah satu disiplin Ilmu Pendidikan Agama Islam yang diajarkan di Madrasah Tsanawiyah, mata pelajaran fikih ini merupakan mata pelajaran yang mengatur hubungan manusia dengan Allah Swt. (hablum minallah), sesama manusia (hablum minannas), dan dengan makhluk lainnya (hablum ma'al ghairi) baik yang berkaitan dengan urusan ibadah maupun muamalah. ${ }^{8}$ Maka dari itu, mata pelajaran ini sangatlah dekat dan lekat dengan kehidupan sehari-hari peserta didik. Dan seringkali dalam kehidupan sehari-hari tersebut banyak dijumpai berbagai persoalan yang memerlukan pemecahan dari segi keilmuan agama terutama dibidang ilmu fikih. Sehingga mata pelajaran fikih ini sangatlah penting untuk dikuasai oleh peserta didik. Bukan hanya sebatas menguasai materi semata, namun juga haruslah memberikan salah satu kemampuan

7 Dirjen KSKK Madrasah Kemenag RI, Keputusan Menteri Agama Nomor 183 Tahun 2019 Tentang Kurikulum PAI dan Bahasa Arab Pada Madrasah (Kementrian Agama RI, 2019), hlm. 51-53.

${ }^{8}$ Dirjen KSKK Madrasah Kemenag RI, hlm. pemecahan masalah sebagai alternatif dalam memecahkan masalah yang muncul dalam kehidupan sehari-hari. Meskipun kemampuan dalam memecahkan masalah seseorang berkaitan dengan kecerdasan yang dimilikinya, termasuk kecerdasan sosial dan spiritual. ${ }^{9}$ Namun kemampuan tersebut dapat dikembangkan dan diting-katkan.

Fakta yang peneliti temukan di lapangan selama beberapa hari pelaksanaan pembelajaran jarak jauh dilakukan di MTs Nidhomiyah, guru mengalami kesulitan memastikan apakah siswa mengerjakan tugas yang diberikan atau tidak. Selain itu, siswa kesulitan memahami instriksi guru karena tidak adanya buku panduan khusus pembelajaran jarak jauh dan berakibat pada rendahnya kemampuan pemecahan masalah yang dikuasai peserta didik. Dari kelas yang peneliti observasi di kelas VII tahun ajaran 2020/2021, kelas VII A hanya ada 8\% dari 25 siswa ( 2 siswa) yang mendapat skor tinggi dalam soal yang mengandung unsur pemecahan masalah. Sedangkan di kelas VII B hanya ada 7,7\% dari 26 siswa ( 2 anak) yang mendapat skor tinggi. Pada kelas VII C hanya ada 3 anak dari 26 siswa (11,5\%) yang mendapat skor tinggi dalam soal yang mengandung unsur pemecahan masalah. Jika keadannya demikian, maka dorongan pemerintah agar peserta didik memiliki kecakapan abad 21 akan sulit terealisasi dan berakibat pada ketidakberhasilan dalam mencapai tujuan pendidikan.

Guna memberikan solusi dari permasalahan di atas, perlu adanya pendekatan pembelajaran yang tepat dan efektif selama pembelajaran jarak jauh berlangsung. Terutama pada mata pelajaran fikih. Dalam memilih pendekatan pembelajaran yang akan digunakan terutama pembelajaran pendidikan agama, termasuk di dalamnya adalah mata pelajaran fikih, seorang guru haruslah terlebih dahulu menganalisis kondisi pembelajaran agama yang ada.

9 Ullin Nuril Farida dan Badrus, "Hubungan Tingkat Kecerdasan Spiritual Dan Kecerdasan Sosial Terhadap Self Efficacy Pada Siswa Kelas XI Di MAN 4 Madiun," Jurnal Intelektual: Jurnal Pendidikan Dan Studi Keislaman 9, no. 01 (30 April 2019): hlm. 28-30, https://doi.org/10.33367/ji.v9i01.964. 
Dengan begitu, ia akan memperoleh gambaran yang jelas tentang bagaimana kondisi pembelajaran dan bagaimana seharusnya pembelajaran itu dilakukan dan apa hasil yang diharapkan. ${ }^{10}$ Jadi, selain menguasai materi yang akan disampaikan, seorang guru haruslah dapat memilih pendekatan pembelajaran atau metode yang sesuai dengan karakteristik mata pelajaran dan keadaan peserta didik agar proses pembelajaran dapat berjalan dengan efektif dan efisien. ${ }^{11}$ Termasuk dalam pembelajaran jarak jauh.

Ada banyak pendekatan pembelajaran yang sudah dikembangkan para tokoh. Namun, dalam penelitian ini, akan digunakan pendekatan SAVI (somatic auditory visualization intellectually), yang dikembangkan pada pembelajaran jarak jauh. Pendekatan SAVI dipilih karena pendekatan ini sangatlah cocok diterapkan pada pembelajaran fikih yang bertujuan memberikan pemahaman pokok-pokok ibadah dan muamalah. ${ }^{12}$ Pendekatan SAVI merupakan pendekatan yang menggabungkan gerakan fisik dengan aktivitas intelektual, serta melibatkan seluruh indra untuk memberikan pengaruh yang besar dalam pembelajaran. ${ }^{13}$ Aktivitas intelektual di sini adalah kegiatan belajar yang mengajak peserta didik untuk memecahkan masalah, menganalisis pengalaman, merumuskan pertanyaan, menciptakan makna pribadi, atau bisa juga dengan meramalkan implikasi suatu gagasan. ${ }^{14}$

Melalui pendekatan ini, peserta didik diajak untuk berpartisipasi aktif dalam pembelajaran, yaitu dengan learning by doing (somatic), learning by hearing (auditory), learning by seeing (visualization), dan

10 Muhaimin, Paradigma Pendidikan Islam (Bandung: PT. Remaja Rosdakarya, 2004), h. 195.

11 Miftahul Huda, Model-model Pengajaran dan Pembelajaran: Isu-isu Metodis dan Paradigmatis (Yogyakarta: Pustaka Pelajar, 2014), h. 184.

12 Dirjen KSKK Madrasah Kemenag RI, Keputusan Menteri Agama Nomor 183 Tahun 2019 Tentang Kurikulum PAI dan Bahasa Arab Pada Madrasah, h. 29-30.

13 Dave Meier, The Accelerated Leraning Handbook: Panduan Kreatif Dan Efektif 80 learning by thinking (intellectually).15 Dalam pembelajaran dengan pendekatan SAVI, seluruh indra akan dilibatkan dalam proses pembelajaran, termasuk didalamnya saluran visual dan auditory. Sehingga pendekatan ini akan menjadi salah satu alternatif dalam pembelajaran jarak jauh dengan memanfaatkan media yang melibatkan kedua indra tersebut. Selain itu, karena di dalamnya terdapat aktivitas intelektual, maka pembelajaran akan semakin efektif dan peserta didik dapat terasah kemampuannya dalam pemecahan masalah.

\section{Metode}

Penelitian ini menggunakan pendekatan penelitian dan pengembangan (research \& development) dengan menggunakan model penelitian dan pengembangan pendidikan yang dikembangkan oleh Borg and Gall. Menurut Borg and Gall, riset dan pengembangan bidang pendidikan ( $\&$ \& $)$ merupakan sebuah proses yang untuk mengembangkan dan mengesahkan produk bidang pendidikan. Langkah-langkah dalam penelitian ini pada umumnya terdiri dari: pengkajian hasil-hasil penelitian sebelumnya yang terkait dengan validitas komponen-komponen pada produk yang akan dikembangkan, mengembangkannya menjadi sebuah produk, pengujian terhadap produk yang dirancang, dan peninjauan ulang dan mengoreksi produk tersebut berdasarkan hasil uji coba. ${ }^{16}$ Dalam tahap pengembangan produk awal, penelitian ini menggunakan model ADDIE yang disederhanakan menjadi 3 langkah, yaitu tahap analisis, desain produk awal, dan pengembangan produk awal. Untuk menguji kela-

Merancang Program Pendidikan Dan Pelatihan (terj. Rahmani Astuti) (Bandung: Kaifa, 2004), h. 91.

14 Meier, h. 100.

15 Huda, Model-model Pengajaran dan Pembelajaran: Isu-isu Metodis dan Paradigmatis, h. 284 .

16 H.R Taufiqurrahman, "Model Penelitian Pengembangan Borg and Gall (1983)," taufiq.net (blog), diakses 30 Juni 2020, https://www.taufiq.net/2019/09/modelpenelitian-pengembangan-borg-and.html. 
yakan model yang dikembangkan dalam penelitian pengembangan, tahapan uji coba model merupakan tahapan yang sangat penting. Tahap uji coba ini dilakukan untuk mengetahi keefektivan sebuah produk yang dikembangkan. Dan desain penelitian yang direkomendasikan untuk menguji coba model adalah desain eksperimen. Dalam penelitian ini, bentuk desain eksperimen yang digunakan adalah pretest-posttest control group desain. ${ }^{17}$

Penelitian ini dilakukan di MTs Nidhomiyah Surowono Kec. Badas Kab. Kediri tepatnya di kelas VII tahun ajaran 2020/2021. Kelas VII A digunakan sebagai kelas eksperimen, dan kelas VII B sebagai kelas kontrol. Sedangkan dalam pengumpulan data, teknik yang digunakan adalah observasi, wawancara, dan tes.

\section{Uji Validitas Dan Reliabilitas}

Agar instrumen yang digunakan valid dan reliabel, maka instrumen tersebut harus diuji validitas dan reliabilitasnya. Untuk memudahkan penghitungan, akan dilakukan uji validitas dan reliabilitas dengan bantuan SPSS 21. Kriteria validitas intstrumen adalah jika $r$ hitung $>r$ tabel pada taraf signifikan 0,05 , maka instrument valid. Sebaliknya, jika $r$ hitung $<r$ tabel, maka instrumen tidak valid. Dalam perhitungan uji validitas soal tes yang telah peneliti lakukan dari 30 item soal, ada 7 item yang tidak valid, kemudian ketujuh item tersebut peneliti hilangkan sehingga didapatkanlah 23 item soal yang valid. Sedangkan dari uji reliabilitas didapat hasil koefisien reliabilitas instrumen tes adalah 0,83 . Ini berarti bahwa instrumen tersebut termasuk dalam kategori sangat tinggi reliabilitasnya.

\section{Taraf Kesukaran}

Tingkat kesukaran soal merupakan karakteristik pernyataan soal yang dapat menunjukkan seberapa mudah atau seberapa sukar soal tersebut. Tingkat kesukaran tes dalam penelitian ini akan dihitung menggunakan bantuan SPSS 21. Indeks tingkat kesukaran (P) tiap pernyataan soal dapat dilihat pada tabel berikut:

Tabel 1 Indeks Tingkat Kesukaran Pernyataan Soal

\begin{tabular}{cc}
$\begin{array}{c}\text { Tingkat } \\
\text { Kesukaran } \\
\text { (P) }\end{array}$ & Interpretasi/penafsiran \\
\hline $0,00-0,30$ & Sukar \\
$0,30-0,70$ & Sedang \\
$0,70-1,00$ & Mudah \\
\hline
\end{tabular}

(Suharsimi Arikunto, 2008: 208)

Dari tes yang peneliti gunakan, terdapat 1 soal sukar, 13 soal sedang, dan 9 soal mudah.

\section{Daya beda soal}

Daya pembeda soal adalah pengukuran sejauh mana suatu soal dapat membedakan peserta didikyang belum atau sudah menguasai kompetensi berdasarkan kriteria tertentu. Semakin tinggi koefisien daya pembeda suatu soal, semakin baik soal tersebut dalam membedakan antara peserta didik yang menguasai kompetensi dengan peserta didik yang kurang menguasai kompetensi. Adapun kualifikasi daya pembeda terbagi dalam empat kategori.

Tabel 2 Kategori Daya Beda

\begin{tabular}{cc}
\hline Batasan & Kategori \\
\hline $0,00<D \leq 0,20$ & Kurang \\
$0,21<D \leq 0,40$ & Cukup \\
$0,41<D \leq 0,70$ & Baik \\
$0,71<D \leq 1,0$ & Baik sekali \\
\hline
\end{tabular}

(Suharsimi Arikunto, 2013: 232)

\section{Uji normalitas}

Uji normalitas merupakan sebuah prosedur untuk mengetahui apakah sebuah data penelitian terdistribusi normal atau dalam sebaran normal. Uji normalitas dalam penelitian ini menggunakan SPSS 21 . Kriteria pengujiannya adalah jika $\mathrm{L}$ hit $<\mathrm{L}$ tab dengan taraf signifikansi 0,05 maka variabel tersebut berdistribusi normal, demikian pula sebaliknya. Hasil ini dapat diketahui dengan melihat signifikan pada kolom

17 Sugiyono, Metode Penelitian Pendidikan (Pendekatan Kuantitatif, Kualitatif, dan R\&D), 19 ed. (Bandung: Alfabeta, 2014), h. 112. 
Kolmogorov-Smirnov. Apabila nilai signifykansi atau nilai probabilitas yang ditunjukkan pada kolom Kolmogorov-Smirnov lebih besar dari nilai alpha atau tingkat kesalahan yang ditetapkan $(>0,05)$ maka data dinyatakan berdistribusi normal.

\section{Uji homogenitas}

Pengujian homogenitas dilakukan untuk mengetahui apakah data sampel yang diambil dari populasi itu bervarians homogen atau tidak. Pengujian homogenitas dilakukan dengan membandingkan nilai signifikan, dengan ketentuan jika nilai Sig > Alpha (0.05) maka data bersifat homogen. Dalam penelitian ini, uji homogenitas data yang digunakan adalah Lavene Tes dengan menggunakan SPSS 21.

\section{Gain Score/ Efektifitas}

Gain Score adalah selisih antara data dari Pretest dan Posttest. Dari hasil perhitungan ini, dapat diketahui efektifitas penggunaan pendekatan SAVI yang dalam penelitian ini gain Sacore dihitung dengan bantuan program SPSS 21. Tingkat efektivitas berdasarkan rata-rata gain ternormalisasi dapat dilihat pada tabel berikut:

Tabel 3 Tingkat Efektivitas

\begin{tabular}{ccc}
\hline $\begin{array}{c}\text { Rata-Rata } \\
\text { Nilai Gain } \\
\text { Ternormalisa } \\
\text { si }\end{array}$ & $\begin{array}{c}\text { Klasifikas } \\
\mathbf{i}\end{array}$ & $\begin{array}{c}\text { Tingkat } \\
\text { Efektvita } \\
\mathbf{s}\end{array}$ \\
\hline $\mathrm{g} \geq 0,70$ & Tinggi & Efektif \\
$70>\mathrm{g}>30$ & Sedang & Cukup \\
$\mathrm{g} \leq 30$ & Rendah & efektif \\
& & Kurang \\
& & efektif \\
\hline
\end{tabular}

(Hake, 1999:1)

\section{Uji T}

Pengujian hipotesis menggunakan bantuan program SPSS 21. Apabila hasil analisis menunjukkan adanya perbedaan efektivitas antara variable bebas, maka selanjutnya analisis dilanjutkan guna meng-

18 Meier, The Accelerated Leraning Handbook: Panduan Kreatif Dan Efektif 82 uji signifikansi perbedaan yang ada dengan menggunakan uji independent sampel t test.

\section{Temuan dan Pembahasan Pendekatan SAVI}

Pendekatan SAVI merupakan salah satu pendekatan pembelajaran yang diperkenalkan oleh Dave Meier, salah seorang Director Center For Accelerated Learning di Lake Ganava. Unsur-unsur dalam pendekatan SAVI ada empat, yaitu: 1) somatis, yakni belajar dengan bergerak dan berbuat; 2) auditori, yakni belajar dengan berbicara dan mendengar; 3) visual, yakni belajar dengan mengamati dan menggambarkan; dan 4) intelektual, yakni belajar dengan memecahkan masalah dan merenung. Dan keempat unsur ini harus ada dalam proses pembelajaran, agar belajar dapat berlangsung dengan optimal.

Siklus pembelajaran dengan pendekatan SAVI terdiri atas empat tahap, yaitu: 1) tahap persiapan; 2) tahap penyampaian; 3) tahap pelatihan; dan 4) tahap penampilan hasil.

Tahap persiapan merupakan tahapan untuk membuat peserta didik benar-benar siap untuk belajar. Hal ini bertujuan untuk membuat peserta didik keluar dari mental yang pasif menjadi aktif dan merangsang minat serta rasa ingin tahunya. ${ }^{18}$

Tahap penyampaian dalam belajar bukan hanya sesuatu yang dilakukan oleh guru/pendidik, tetapi secara aktif melibatkan peserta didik dalam menciptakan pengetahuan dalam setiap langkahnya. Tujuan tahapan ini adalah membantu peserta didik menemukan materi yang baru dengan cara menarik, menyenangkan, relevan, multi indra, dan cocok untuk semua gaya belajar.

Tahap pelatihan merupakan tahapan inti dari SAVI. Apapun yang dipikirkan, dikatakan, serta dilakukan pembelajarlah yang menciptakan pembelajaran, bukannya yang dipikirkan, dikatakan, maupun dilakukan oleh guru/pendidik. Tahapan ini bertujuan untuk membantu peserta didik mengintegrasikan dan memadukan pengetahuan serta ketrampilan barunya dengan aneka macam cara.

Merancang Program Pendidikan Dan Pelatihan (terj. Rahmani Astuti), h 119-121.

el Bidayah: Journal of Islamic Elementary Education Volume 2, Nomor 2, September 2020 
Tahapan penampilan hasil bertujuan untuk memastikan bahwa pembelajaran yang telah dilaksanakan tetap melekat dan prestasi terus meningkat.

\section{Pembelajaran Jarak Jauh}

Penyelenggaraan pembelajaran jarak jauh dapat dilakukan dalam beberapa bentuk, diantarnya adalah: 1) Program pendidikan mandiri; 2) Program tatap muka diadakan di beberapa tempat pada waktu yang telah ditentukan.; 3) Program tidak terikat pada jadwal pertemuan di satu tempat; 4) e-learning, yaitu pembelajaran online berbasis teknologi informasi via internet. ${ }^{19}$

\section{Pembelajaran Jarak Jauh dengan SAVI}

Dave meier dalam bukunya menyatakan bahwa pembelajaran akan mendapatkan hasil terbaiknya apabila bersifat SAVI (Somatis, Auditori, Visual, dan Intelektual), termasuk di dalamnya adalah pembelajaran jarak jauh. Agar pembelajaran jarak jauh dapat bersifat SAVI, Dave Meier mengungkapkan beberapa gagasan berikut ini.

\section{1) Somatis}

Untuk menciptakan pembelajaran jarak jauh yang somatis, ada beberapa hal yang dapat dilakukan, diantaranya adalah dengan mengajak pelajar melakukan hal-hal seperti: a) Mendapatkan kembali printout; b) Perburuan; c) Menciptakan piktogram; d) Papan permainan; e) Memerankan; f) wawancara pribadi; dan g) Pengamatan pribadi. ${ }^{20}$

\section{2) Auditori}

Gagasan pembelajaran jarak jauh agar tetap bersifat auditori adalah dengan melakukan hal-hal seperti: a) Pengenalan auditori; b) Dialog pembelajar; c) Tinjauan konser; d) Membaca keras-keras; e) Kaset tanya jawab; f) Wawancara; dan g) Berpikir dengan lantang. ${ }^{21}$

19 Munir, Pembelajaran Jarak Jauh berbasis Teknologi Informasi dan Komunikasi (TIK) (Bandung: CV. Alfabeta, 2009), h. 23-24.

20 Meier, The Accelerated Leraning Handbook: Panduan Kreatif Dan Efektif Merancang Program Pendidikan Dan Pelatihan (terj. Rahmani Astuti), hlm. 264-265.

${ }^{21}$ Meier, hlm. 266-267.

el Bidayah: Journal of Islamic Elementary Education

Volume 2, Nomor 2, September 2020
3) Visual

Agar pembelajaran jarak jauh dapat bersifat visual, Dave Meier menyarankan untuk dilakukan seperti: a) Peta kursus; b) Bahasa gambar; c) Grafik; d) Cerita; e) Contoh video; dan f) Pengamatan dunia nyata. 22

4) Intelektual

Agar pembelajaran jarak jauh bersifat intelektual dapat dilakukan dengan: a) Perolehan informasi; b) Pemecahan masalah; c) Pemetaan konseptual; dan d) renungan. 23

\section{Kemampuan Pemecahan Masalah Mata Pelajaran Fikih}

Kemampuan pemecahan masalah adalah kesanggupan atau kecakapan peserta didik dalam memecahkan permasalahan dan menemukan solusi/ ja-waban secara rasional, lugas, dan tuntas serta melatih melakukan proses penelitian untuk menemukan informasi-informasi yang diperlukan dalam mencapai tujuan belajar sehingga dapat memperoleh kesimpulan yang meyakinkan karena didukung oleh data.

Sedangkan pengertian fikih berdasarkan KMA Nomor 183 Tahun 2019 tentang Kurikulum PAI dan Bahasa Arab Pada Madrasah adalah sebuah sistem atau seperangkat aturan syari'at yang berkaitan dengan perbuatan manusia (mukallaf) dalam kehidupan sehari-hari untuk memenuhi kebutuhan manusia, baik terkait hubungan manusia dengan Allah Swt. (hablum minallah), sesama manusia (hablum minannas) maupun dengan makhluk lainnya (hablum ma 'al ghairi).24 Maka dapat disimpulkan kemampuan pemecahan masalah mata pelajaran fikih adalah kesanggupan peserta didik dalam memecahkan masalah yang berkaitan dengan hablum minallah, hablum minannas, dan hablum ma 'al ghairi serta mencari solusi dari permasalahan tersebut.

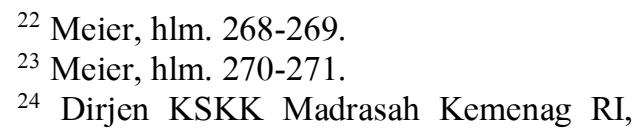
Keputusan Menteri Agama Nomor 183 Tahun 2019 Tentang Kurikulum PAI dan Bahasa Arab Pada Madrasah, hlm. 55. 
Pada masa abad ke-21 saat ini, dunia semakin berkembang dan permasalahan yang muncul semakin kompleks. Termasuk pula di dalamnya yang berkaitan dengan hukum-hukum Islam dalam pelajaran fikih. Oleh karena itu, pembelajaran fikih haruslah mengajarkan pemecahan masalah yang berkaitan dengan kehidupan sehari-hari terutama yang berkaitan dengan hukumhukum agama dengan tujuan membantu peserta didik mempersiapkan diri agar dapat menjalankan perbuatan yang baik dan ibadah sesuai ketentuan.

\section{Tahap Penelitian Dan Pengumpulan Informasi}

Pada tahapan ini, peneliti mengumpulkan informasi dengan studi pustaka dan kurikulum serta studi lapangan. Kegiatan studi lapangan dilakukan untuk memperoleh informasi kondisi pembelajaran di kelas VII MTs Nidhomiyah Surowono selama pembelajaran jarak jauh. Berdasarkan hasil observasi dan wawancara, diperoleh data berikut ini:

a. Pembelajaran jarak jauh masa pandemi yang dilakukan di MTs Nidhomiyah pada mata pelajaran fikih masih sebatas pemberian tugas yang ada di buku LKS melalui grup whatsapp dan tidak ada umpan balik.

b. Pembelajaran yang dilakukan tidak menggunakan pendekatan yang dapat membangkitkan daya kritis dalam pemecahan masalah.

c. Kemampuan pemecahan masalah peserta didik rendah.

d. Peserta didik memerlukan sebuah pendekatan pembelajaran jarak jauh yang tepat dan dapat digunakan siswa selama belajar dari rumah.

Studi pustaka dan kurikulum dilakukan dengan mengkaji Kompetensi Inti dan Kompetensi Dasar (KI KD) mata pelajaran Fikih yang dimuat di dalam KMA Nomor 183 dan 184 Tahun 2019, karakteristik mata pelajaran fikih, teori tentang strategi dan pendekatan pembelajaran, dan hasil-hasil penelitian tentang pembelajaran jarak jauh.
Dalam tahapan ini pula peneliti mengumpulkan referensi materi yang dibutuhkan dalam pengembangan pendekatan pembelajaran. Dari hasil studi pustaka dan kurikulum, dipilih 1 materi pokok yang menjadi sasaran pengembangan. Materi pokok tersebut adalah tentang salat sunnah.

\section{Tahap Perencanaan}

Tahapan perencanaan merupakan penyusunan rencana rancangan pengembangan pendekatan pembelajaran SAVI melalui pembelajaran jarak jauh. Tahapan ini dibagi dalam empat komponen perencanaan yaitu penyusunan rancangan panduan pembelajaran, penyusunan rancangan RPP, penyusunan rancangan instrumen validasi oleh ahli desain, dan penyusunan rancangan instrumen tes.

\section{Tahap Pengembangan Produk Awal}

Pengembangan produk awal dalam penelitian ini menggunakan pengembangan model ADDIE yang disederhanakan menjadi tiga langkah karena terbatasnya waktu dan kemampuan yang peneliti miliki. Langkahlangkah pengembangannya meliputi tahap analisis, desain produk awal, dan pengembangan produk awal. Tahap pengembangan produk awal ini meliputi: 1) pengembangan RPP beserta bahan ajar dan media yang sesuai tujuan pembelajaran; 2) pengembangan panduan pembelajaran untuk guru dan siswa; dan 3) Validasi ahli desain dan ahli materi. Setelah mendapat validasi dari ahli desain dan ahli materi, produk awal diperbaiki berdasarkan saran yang ada.

\section{Uji Coba Pendahuluan}

Setelah pengembangan pendekatan pembelajaran selesai divalidasi dan diperbaiki berdasarkan saran dari ahli kemudian diimplementasikan untuk diuji cobakan kepada 6 siswa MTs Nidhomiyah kelas VII sebagai kelompok eksperimen dan 6 siswa yang lain sebagai kelompok kontrol yang masing-masing memiliki kemampuan pemecahan masalah rendah, sedang, dan tinggi. Tahapan uji coba ini bertujuan untuk mengetahui efektivitas pendekatan pembelajaran yang dikembangkan. Uji coba dilaksanakan pada tanggal 12 Agustus 2020. Dari hasil uji coba, diperoleh hasil bahwa nilai 
rata-rata N-gain score untuk kelas eksperimen (dengan pendekatan SAVI) adalah sebesar 38,6387 atau 38,6\% termasuk dalam kategori cukup efektif. Sementara untuk kelas kontrol (metode pemberian tugas) nilai rata-rata $\mathrm{N}$-gain scorenya ada-lah sebesar 8,5228 atau 8,5\%. Hal ini menunjukkan bahwa penggunaan pengembangan pendekatan SAVI melalui pembelajaran jarak jauh cukup efektif dalam meningkatkan kemampuan pemecahan masalah pada mata pelajaran fikih. Sementara metode pemberian tugas kurang efektif dalam meningkatkan kemampuan pemecahan masalah pada mata pelajaran fikih melalui pembelajaran jarak jauh. Sedangkan hasil yang diperoleh pada tabel output independent samples test, diketahui nilai sig. (2-tailed) sebesar 0,045<0,05. Dengan demikian dapat disimpulkan bahwa ada perbedaan efektivitas yang signifikan (nyata) antara penggunaan pengembangan pendekatan SAVI dengan metode pemberian tugas untuk meningkatkan kemampuan pemecahan masalah pada mata pelajaran fikih melalui pembelajaran jarak jauh.

\section{Revisi Produk Utama}

Setelah melakukan uji coba, peneliti kemudian memberikan angket kepada responden uji coba untuk dimintai penilaian dan pendapatnya mengenai pembelajaran dengan pendekatan SAVI.

Dari angket yang peneliti berikan kepada responden, didapat hasil skor ratarata 80 dan masuk dalam kategori baik. Beberapa responden memberikan catatan bahwa mereka merasa kesulitan mencari halaman yang ingin mereka tuju karena tidak adanya daftar isi. Oleh karena itu, peneliti melakukan revisi pada panduan pembelajaran untuk guru dan panduan belajar bagi siswa dengan menambahkan halaman daftar isi. Selebihnya, responden mengaku bahwa mereka merasa menjadi lebih mudah dalam memahami materi.

\section{Uji Coba Utama}

Setelah diadakan revisi, tahapan selanjutnya adalah uji coba utama. Uji coba ini dilaksanakan pada tanggal 13 dan 14 Agustus 2020. Uji coba dilakukan pada kelas kelas VII A sebagai kelas eksperimen yang mendapat perlakukan pendekatan pembelajaran SAVI. Sedangkan untuk kelas kontrol dipilih kelas VII B dengan perlakuan metode pemberian tugas. Sebelum pembelajaran dimulai, kedua kelompok diberikan pretest dan setelah pembelajaran diberikan posttest. Kemudian hasil pretest dan posttest dibandingkan untuk mengetahui perbedaan hasil dari kedua kelompok ini.

Dari hasil uji coba diperoleh hasil bahwa nilai rata-rata N-gain score untuk kelas eksperimen (dengan pendekatan SAVI) adalah sebesar 33,5513 atau 33,6\% termasuk dalam kategori cukup efektif. Dengan nilai $\mathrm{N}$-gain minimal $-9,6 \%$ dan maksimal $90,7 \%$. Sementara untuk kelas kontrol (metode pemberian tugas) diperoleh ratarata $\mathrm{N}$-gain score sebesar 16,1496 atau $16,15 \%$ dengan $\mathrm{N}$-gain minimum $-9,62$ dan maksimum 66,67. Sedangkan uji independent sampel t test menghasilkan nilai sig. (2tailed) sebesar 0,014 .

\section{Efektivitas Pengunaan Pendekatan SAVI Melalui Pembelajaran Jarak Jauh}

Untuk mengetahui efektivitas pengembangan pendekatan SAVI melalui pembelajaran jarak jauh dalam meningkatkan kemampuan pemecahan masalah, dilakukanlah uji coba utama. Uji coba utama dilakukan pada kelas VII A sebanyak 25 siswa sebagai kelas eksperimen, dan kelas VII B sebanyak 26 siswa sebagai kelas kontrol. Sebelum pembelajaran dimulai, dilakukan pretest dan setelah pembelajaran dilakukan post-test yang kemudian dibandingkan untuk diketahui perbedaan hasil antara kelompok kontrol dengan kelompok eksperimen.

Berdasarkan hasil tersebut, diperoleh nilai pre test minimal 26 dan maksimal 78 pada kelas eksperimen, dengan rata-rata kelas 52. Dari 25 siswa, hanya 3 anak yang mendapat nilai 70 ke atas. Namun, setelah mendapat perlakuan pembelajaran dengan pendekatan SAVI, diperoleh nilai post test minimal 43 dan maksimal 96, sedangkan rata-rata kelas menjadi 67, dengan 13 anak mendapat nilai 70 ke atas.

Sedangkan pada kelas kontrol, diperoleh hasil pre test minimal 22 dan maksimal 74. Rata-rata kelas 49 dan hanya ada 4 anak yang mendapat nilai 70 ke atas. 
Setelah mendapat perlakuan pembelajaran dengan metode pemberian tugas, di dapat nilai post test minimal 30 dan maksimal 87. Sedangkan rata-rata kelasnya adalah 56 dengan 7 anak yang mendapat nilai $70 \mathrm{ke}$ atas.

Setelah diperoleh hasil pretest dan posttest kelompok eksperimen dan kelompok kontrol, langkah selanjutnya adalah menghitung efektivitas atau Gain Score dengan bantuan aplikasi SPSS 21. Berdasarkan output tabel $\mathrm{N}$-gain score, diperoleh rata-rata $\mathrm{N}$-gain score kelas eksperimen sebesar 33,5513 atau 33,6\%. Dengan nilai $\mathrm{N}$-gain minimal $-9,6 \%$ dan maksimal 90,7\%. Hasil rata-rata N-gain score tersebut termasuk dalam kriteria sedang atau cukup efektif. Sedangkan ratarata N-gain score kelas kontrol diperoleh hasil sebesar 16,1496 atau $16,15 \%$ dengan N-gain minimum -9,62 dan maksimum 66,67. Hasil ini termasuk dalam kriteria rendah atau kurang efektif.

Hasil ini menunjukkan bahwa penggunaan pengembangan pendekatan SAVI melalui pembelajaran jarak jauh cukup efektif dalam meningkatkan kemampuan pemecahan masalah pada mata pelajaran fikih. Sementara metode pemberian tugas kurang efektif dalam meningkatkan kemampuan pemecahan masalah pada mata pelajaran fikih melalui pembelajaran jarak jauh. Berdasarkan hasil uji coba utama tersebut, terlihat adanya perbedaan efektivitas antara pembelajaran yang menggunakan pendekatan SAVI dengan pembelajaran yang menggunakan metode pemberian tugas. Oleh karena itu selanjutnya dilakukanlah uji independent sampel $t$ test untuk mengetahui signifikansi dari per-bedaan keduanya.

Sebelum dilakukan uji independent sampel t test, terlebih dahulu dilakukan uji normalitas sebagai salah satu prasyarat uji t. Dari uji normalitas yang telah dilakukan, diperoleh hasil sebagai berikut.

\begin{tabular}{|c|c|c|c|c|c|c|c|}
\hline & & $\begin{array}{l}\text { Stat } \\
\text { istic }\end{array}$ & df & Sig. & $\begin{array}{l}\text { Stat } \\
\text { istic }\end{array}$ & df & Sig. \\
\hline \multirow{4}{*}{$\begin{array}{l}\text { NGain_ } \\
\text { Persen }\end{array}$} & Eksp & ,13 & 25 & ,20 &, 94 & 25 & 153 \\
\hline & erime & 8 & & $0^{*}$ & 1 & & \\
\hline & $\begin{array}{l}\mathrm{n} \\
\text { Kontr }\end{array}$ & 16 & 26 & 06 & 87 & 26 & 005 \\
\hline & & 5 & & 7 & 9 & & \\
\hline
\end{tabular}

*. This is a lower bound of the true significance.

a. Lilliefors Significance Correction

Berdasarkan tabel output test of normality diatas, diketahui nilai signifikansi (sig.) dalam Uji Kolmogorov Smirnov untuk nilai Ngain_Persen pada kelas eksperimen adalah sebesar 0,200 dan kelas kontrol sebesar 0,067. Karena nilai Sig. kedua kelas tersebut lebih besar dari 0,05 maka dapat dikatakan bahwa data yang digunakan dalam penelitian ini berdistribusi normal. Dengan demikian uji prasyarat penggunaan uji independet sampel t test untuk $\mathrm{N}$-gain score sudah terpenuhi. Uji normalitas kolmogorov smirnov dipilih karena jumlah sampel yang digunakan untuk kedua kelas tersebut lebih dari 50 buah. Langkah selanjutnya adalah menguji N-Gain score dengan bantun SPSS 21.

Berdasarkan tabel output independet sampel $t$ test diketahui bahwa nilai signifikansi (Sig.) pada Lavene's Test for Equality of Variances adalah sebesar 0,019 $<0,05$. Hal ini menunjukkan bahwa varians data N-Gain (\%) untuk kelas eksperimen dan kelas kontrol tidak sama atau tidak homogen. Maka uji independent sampel $t$ test untuk N-Gain score berpedoman pada nilai Sig. yang terdapat pada tabel Equal Variances Not Assumed. Nilai sig. (2-tailed) yang diperoleh pada tabel Equal Variances Not Assumed sebesar 0,014<0,05. Dengan demikian, dapat disimpulkan bahwa adanya perbedaan efektivitas bersifat signifikan (nyata) antara penggunaan pendekatan SAVI dengan metode pemberian tugas dalam meningkatkan kemampuan pemecahan masalah pada mata pelajaran fikih melalui pembelajaran jarak jauh.
Tabel 4 Output Uji Normalitas NGain

Tests of Normality Persen

\section{Kesimpulan}

Berdasarka uraian pembahasan, dapat disimpulkan hal-hal sebagai berikut:

1. Berdasarkan langkah pertama ini, dipilih satu materi pokok yang akan menjadi 
sasaran pengembangan, yaitu tentang salat sunnah. Kedua, tahap perencanaan yang meliputi penyusunan rancangan panduan pembelajaran, rancangan RPP, rancangan instrumen validasi ahli desain, dan rancangan instrumen tes. Keti$g a$, tahap pengembangan produk awal yang terdiri dari tahap analisis, desain produk awal, dan pengembangan produk awal. Setelah panduan pembelajaran, insrumen tes, dan RPP dikembangkan, kemudian dimintakan validasi ahli desain dan ahli materi. Setelah mendapat validasi, produk kemudian diperbaiki berdasarkan saran dari para ahli. Keempat, tahap uji coba pendahuluan. Setelah dilakukan uji coba pendahuluan, responden diberikan angket untuk mengetahui respon dan saran siswa terhadap pembelajaran yang dilakukan. Kelima, tahap revisi produk utama. Pada tahap ini, produk yang dikembangkan kemudian diperbaiki berdasarkan masukan dari responden. Keenam, tahap uji coba utama. Produk yang telah dikembangkan dan diperbaiki, kemudian diujikan pada kelas ekperimen yang dibandingkan dengan kelas kontrol untuk mengetahui efektifitasnya.

2. Pendekatan SAVI cukup efektif dalam meningkatkan kemampuan pemecahan masalah yang dikuasai siswa. Hal ini dapat dilihat berdasarkan hasil dari pre test dan pos test pada kelas eksperimen yang dibandingkan dengan kelas kontrol. Dari kelas eksperimen diperoleh hasil pre test memiliki rata-rata 52 namun setelah mendapat perlakuan pendekatan SAVI diperoleh nilai post test 67. Jauh berbeda dengan kelas kontrol yang nilai rata-rata kelas yang awalnya adalah 49 menjadi 56. Hal ini didukung pula dengan hasil rata-rata $\mathrm{N}$ gain score kelas eksperimen sebesar 33,5513 atau 33,6 yang masuk dalam kriteria sedang atau cukup efektif. .

\section{Daftar Pustaka}

COVID-19, Gugus Tugas Percepatan Penanganan. "Beranda | Gugus Tugas Percepatan Penanganan COVID-19." covid19.go.id. Diakses 26 Juni 2020. https://covid19.go.id/.

Depdiknas. Undang-undang RI Nomor 20 Tahun 2003 Tentang Sistem Pendidikan Nasional, 2003.

Dirjen KSKK Madrasah Kemenag RI. Keputusan Menteri Agama Nomor 183 Tahun 2019 Tentang Kurikulum PAI dan Bahasa Arab Pada Madrasah. Kementrian Agama RI, 2019.

Farida, Ullin Nuril, dan Badrus. "Hubungan Tingkat Kecerdasan Spiritual Dan Kecerdasan Sosial Terhadap Self Efficacy Pada Siswa Kelas XI Di MAN 4 Madiun." Jurnal Intelektual: Jurnal Pendidikan Dan Studi Keislaman 9, no. 01 (30 April 2019): 25-34. https://doi.org/10.33367/ji.v9i01.96 4.

Fuad, A. Jauhar, dan Hamam. Teori dan Praktik Penelitian Tindakan Kelas (PTK). Tulungagung: STAIN Tulungagung Pers, 2012.

Huda, Miftahul. Model-model Pengajaran dan Pembelajaran: Isu-isu Metodis dan Paradigmatis. Yogyakarta: Pustaka Pelajar, 2014.

Limbong, Sepriani Trimurtini. "Virus Corona - Penyebab, Gejala dan Pencegahan Klikdokter.com." Diakses 26 Juni 2020.

https://www.klikdokter.com/penyak it/coronavirus.

Meier, Dave. The Accelerated Leraning Handbook: Panduan Kreatif Dan Efektif Merancang Program Pendidikan Dan Pelatihan (terj. Rahmani Astuti). Bandung: Kaifa, 2004.

Muhaimin. Paradigma Pendidikan Islam. Bandung: PT. Remaja Rosdakarya, 2004.

Munir. Pembelajaran Jarak Jauh berbasis Teknologi Informasi dan Komunikasi (TIK). Bandung: CV. Alfabeta, 2009.

Pakpahan, Roida, dan Yuni Fitriani. "Analisa Pemanfaatan Teknologi Informasi 
Dalam Pembelajaran Jarak Jauh Di Tengah Pandemi Virus Corona Covid19." Journal of Information System, Applied, Management, Accounting and Research 4, no. 2 (19 Mei 2020): 3036.

Pangondian, Roman Andrianto, Paulus Insap Santosa, dan Eko Nugroho. "Faktor - Faktor Yang Mempengaruhi Kesuksesan Pembelajaran Daring Dalam Revolusi Industri 4.0." Seminar Nasional Teknologi Komputer \& Sains (SAINTEKS) 1, no. 1 (21 Februari 2019).

https://www.prosiding.seminarid.com/index.php/sainteks/article/vi ew $/ 122$.

Sugiyono. Metode Penelitian Pendidikan (Pendekatan Kuantitatif, Kualitatif, dan R\&D). 19 ed. Bandung: Alfabeta, 2014.

Taufiqurrahman, H.R. "Model Penelitian Pengembangan Borg and Gall (1983)." taufiq.net (blog). Diakses 30 Juni 2020.

https://www.taufiq.net/2019/09/m odel-penelitian-pengembangan-borgand.htm

Thersia, Vita, Muhammad Arifuddin, dan Misbah.

"Meningkatkan Kemampuan Pemecahan Masalah Melalui Pendekatan Somatis Auditori Visual Intelektual (SAVI) dengan Model Pengajaran Langsung." Berkala Ilmiah Pendidikan Fisika 7 (Desember 2018): 19-27. http://dx.doi.org/10.20527/bipf.v7i1 .5638 .

Widad, Aufal. "Tesis Pembelajaran Kooperatif Model SAVI (Somatis, Auditory, Visual, Intelektual) Dalam Mata Pelajaran PAI Di SMAN Balung dan SMAN Ambulu." UIN MALIKI, 2015. 